\section{Multidisciplinary SCIENTIFIC JOURNAL OF MARITIME RESEARCH}

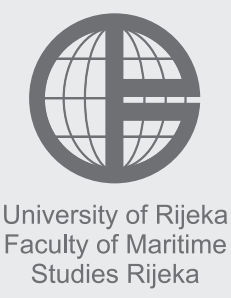

Multidisciplinarni znanstveni časopis POMORSTVO

https://doi.org/10.31217/p.32.2.4

\title{
Natural Capital Preservation in the Coastal Area
}

\author{
Lidija Runko Luttenberger ${ }^{1}$, Ivana Gudelj ${ }^{2}$, Vladimir Hršak ${ }^{2}$ \\ ${ }^{1}$ University of Rijeka, School of Polytechnics, e-mail: lidija.luttenberger@uniri.hr \\ ${ }^{2}$ Croatian Agency for the Environment and Nature
}

\begin{abstract}
The removal of a single tree growing in an urban area or a patch of forest for development purposes is a practice that results from inappropriate economic approach to and unawareness of the value of natural capital and the services it provides. The paper analyses the benefits of the existence of urban trees and discusses valuation methods, emphasizing in particular the value of vegetation in the coastal area of the Republic of Croatia. Due to holistic focus of the topic, a qualitative research is applied based on observations, authors' previous research, experiences, reports on current research and legislation. Several instruments for the preservation and maintenance of vegetation are proposed ranging from the measures by local self-governments, upgrading the system of fees for forest general benefit functions to proper implementation of non-financial reporting which should apply to all companies whose operations may have an impact on natural capital, regardless of their size and ownership structure. National legislation should meet more than a minimum compliance with EU directives and international efforts in standardizing non-financial reporting. Many companies undertake activities that may and do exert pressure on vegetation cover or natural capital, as do also the entities of public interest such as local and regional self-government units and the companies established by them, which should also become liable to non-financial reporting.
\end{abstract}

\section{ART I C L E IN FO}

\section{Review article}

Received 4 November 2018

Accepted 28 November 2018

\section{Key words:}

Natural capital

Coastal area

Coastal vegetation

Non-financial reporting

\section{Introduction}

Coastal areas represent an interface or transition areas between land and the sea. They are diverse in function and form, dynamic and can rarely be defined by spatial boundaries. Coastal areas are a highly vulnerable environment with the highest biological and geological values.

The development in coastal areas is largely associated with intense new construction, which at the same time means removal of natural vegetation cover in the area concerned. That is particularly pronounced in the case of the Republic of Croatia, a country of exceptional natural beauty, biodiversity, geodiversity and rich cultural heritage, which is precisely for that reason exposed to the pressures of new development, particularly along the Adriatic coast.

The paper analyses the issue of valuing or better to say undervaluing of urban vegetation that is cleared in favour of construction and so-called landscaping in coastal area. It also proposes the methods of regulating the issue of felling by way of the measures of local self-governments, by adjusting the fees charged and through the application of sustainable development metrics.

\section{Benefits of Urban Trees in the Coastal Area}

Maintaining of the urban green constitutes an expense and effort. However, the benefits of the presence of urban vegetation by far exceed the costs. It is worth mentioning at least some of them $[1,2,3]$ :

- increasing the value of properties,

- saving the energy required for cooling as a result of controlling solar radiation by shadow that protects the people, soil, impermeable surfaces, buildings and other areas that absorb solar energy and radiate it back into environment,

- saving the energy during summer due to evapotranspiration through surfaces of leaves, thus having an effect on the surrounding air,

- saving the energy by blocking radiant heat loss from homes and people (evidenced by circles below trees in morning frost),

- saving the energy in winter as a result of the reduced effect of the wind,

- protection from erosion due to the increased soil stability on slopes, 
- reduced storm water runoff,

- reduced water pollution, purification of groundwater,

- fruit, wood (for timber, fuel, cellulose, hobbies),

- recreation,

- social interaction,

- noise reduction and producing the sound of leaves and branches that mask other sounds produced by man,

- natural fence,

- protection from unwanted sights, safety,

- habitat for numerous species,

- protection from light pollution,

- extending the lifecycle of road surfaces owing to reduced temperatures achieved by such surfaces during hot days,

- road safety as drivers drive slower and pay greater attention when a tree line is planted along the street,

- creating safety green demarcation line between pedestrians and driving vehicles,

- aesthetic value,

- sentimental value,

- absorption of carbon dioxide (greenhouse gas) and production of oxygen needed for life,

- removal of air pollutants resulting also in reducing health risk,

- health-related benefits in the sense that hospitalized patients having a view of the trees recover faster and

- less sick leave and greater satisfaction at work for employees who may view greenery at workplace.

It may therefore be said that the trees and plants silently and continuously carry out their daily routines stabilizing the soil, recycling the nutrients, cooling the air, modifying wind turbulence, intercepting the rain, absorbing the toxins, reducing fuel costs, neutralizing sewage, increasing property values, enhancing social awareness, providing beauty, cutting noise, giving the privacy, promoting tourism, encouraging recreation, reducing stress and improving personal health, as well as providing food, medicine and accommodation for other living things [4].

The quantification of only one of those benefits was for instance undertaken by the electricity utility company in Sacramento, California for own purposes. Tree benefit estimator computes the number of $\mathrm{kWh}$ and the amount of $\mathrm{CO}_{2}$ saved by any given tree. The figures thus obtained can be used for valuing an existing tree or forecasting the value of a new tree to be planted. The company then allocates a free tree while their web site provides a myriad of good advices on looking after the new specimen. What matters in fact is the shadow provided by the tree for meeting peak demand that is extremely expensive [5].

Chronologically, the trees were already formed in large forests 330 million years ago, while the first human came into existence about 327 million years later. It is therefore clear that we depend on them [4]. Furthermore, the sur- vival ratio of green plant to animals is 99:1 meaning that for survival of one part of animals, including humans, 99 times of their body mass of green coverage is required in their surroundings. Animal population is increasing, therefore the new-borns require ever more green coverage equal 99 times of the newly incorporated human population, but in reality green area cover equivalent to 4 football grounds is vanishing per minute from the face of the Earth. The only option is total halting of deforestation followed by multifold increased activities of afforestation, including extension of green coverage in every corner in rural and urban areas [6].

\section{Valuation of Green Habitat in the Coastal Area}

What constitutes the value of a tree is therefore not only wood (and fruit), but also ecological contribution to the environment, although when a tree comes up for sale, it is often the log buyer, not the ecologist, the one who offers better bid. The value of trees may be estimated not only on the basis of timber products yield, but also from the perspective of real estate value increase, substitution cost, and the sums that people spend in order to use the forest. The goal is to develop a system that will enable land use planners and other agencies to get a realistic estimate of the value of trees from the ecological perspective [7].

There are several methods of valuing the services of forest ecosystems. Apart from those related to market prices of the mass of wood, the value of fruits etc., the nonmarket estimates are mainly assessed applying the method of revealed preferences where personal preferences can be observed within the conditions of real life, and the method of expressed preferences where the statement of the respondent is relied upon. The basic problem hampering the application of their results lies in distrust of the many economists and other experts in the human wish and ability to give a sincere and careful answer to every question. A third group concerns the cost-benefit method, frequently used in comparing different scenarios and their impacts upon the environment or natural resources such as the forest. For its proper application, the values of physical, technical and economic parameters used in the model should be known in advance [8].

The total economic value of the environment does not imply valuing solely the preferences of people towards the use value of the environment. Apart from "direct" use of the environment, people often enjoy just in observing the environment (directly or indirectly). The value of existence is the one that is allocated to environmental asset, but is in no way related to the actual or potential use of the respective asset. People thus advocate the preservation of tropical forests or whales although it is almost certain that they will neither now nor in the future use such a natural value. The sole existence of such species or ecosystems represents a value for them [9].

There is also the value of wilderness to humanity, which is something quite different from controlled and manicured gardens, however beautiful. Furthermore, the 
inherent right of a tree to exist is worth something [10]. In 1972, professor Christopher Stone published the article entitled „Should Trees Have Standing?” advocating that the rights of nature should be recognized by law. Stone realized that for nature to have rights the laws would have to be changed so that (a) a suit could be brought in the name of an aspect of nature such as river, (b) a polluter could be held liable for harming a river and (c) judgements could be made that would benefit a river [11,12].

It is however unlikely that a tree valuation formula will ever be devised that is acceptable to everyone, but the principle is that green assets are valuable in diverse and subtle ways [4]. For instance, a disappearing plant species can take with it 10 to 30 dependent species, such as various species of insects, higher animals and even other plants. When a tree is cut down, the damage inflicted is rather permanent in nature and cannot be recovered immediately. What is more significant, it is not a personal loss, but a loss for the entire whole community [6].

Forests, with their non-market benefits, have an immeasurable value and it is practically impossible to price these benefits using the principles of economic science. The high value of the beneficial forest functions is priceless, and if a price were actually given to them, it would mean that they would be devalued, in the same manner as infinite maternal love may not be given a monetary value [8].

One of the tree pricing equations used to calculate the value of an individual tree in the park and other areas is based on the material value of wood product that is multiplied by factors based on species significance, condition and importance, as well as location of the tree [13]. Therefore, the assessment of ecological impacts is transformed into the following arithmetic steps [14]:

\section{tree value $=\mathrm{dbh}$ area $\times \$$ (value $) \times$ species factor $\times$ location factor $\times$ condition factor}

where dbh is the cross-section area at breast height. The value of a wood product is subject to periodic revision, while other three factors depend greatly on experienced expert judgement.

It has also to be kept in mind that wherever there are more trees, there is a greater rainfall [10]. Namely, vegetation protects the ground from overheating - drying-out and optimizes the amount of evaporation via transpiration through stomata on the leaves. Well soaked by water, the vegetation has a significant cooling effect and air-conditioning capability. Where a vegetation structure is impaired, solar energy falls on the area with low evapotranspiration and a major portion thereof transforms into sensible heat. That leads to significant temperature aberrations and temperature difference between day and night or between the localities having different thermal regime. Air currents increase, water vapour is taken further away by warm air and the bulk of evaporated water is lost from the soil [15].

The plants through which transpiration takes place, particularly the trees, represent a perfect air-conditioning system of the Earth. The tree is at the same time "fuelled" by solar energy only, is made of recyclable materials, requires a minimum amount of maintenance and emits water vapour regulated by millions of stomata that respond to heat and humidity. Solar energy bound up in water vapour is carried away and is released upon its condensation in cool locations. Thus it balances the temperature in time and space, as opposed to refrigerator or air-conditioner that release heat into its nearby surroundings. A tree is, unlike a refrigerator or air conditioner, also noiseless, absorbs noise and dust and binds $\mathrm{CO}_{2}$. Drainage and deforestation lead to the situation that towns, while growing, change the microclimatic conditions of the original territory. They become artificial urban hot islands over which hot climate umbrella grows. These "islands" slowly and surely change the flow of clouds and the movement of winds over their territory and in their surroundings. In particular, during summer, they push precipitation to the colder mountain areas, thus resulting in a higher risk of extreme torrential rain in the mountain regions and floods that threaten the valleys and population in lowlands downstream on rivers. That is a more direct and logical cause for climate changes and rising weather extremes than the impact of a $30 \%$ growth in the fractional $\mathrm{CO}_{2}$ content in the air over the past 150-years period. The old paradigm that considered water as a permanently renewable source collapsed, and the truth is that water is a renewable source only while water cycle is functional [15]. That is where vegetation plays great and significant role.

Would trees, apart from oxygen, also provide some free service such as WiFi, everyone would be planting trees. It is at the same time impossible to obtain the exact figure of the number of trees cut annually at a global level, but according to certain theories, it is assumed to be in the range of 3 to 6 billion trees. It is therefore necessary to control such activity because the forests are lungs of the Earth [16].

One can pose a question how could it happen that we can even attempt to put monetary value on such intangible, subjective, culturally conditioned factors. We are confronted with tremendous undervaluing of natural assets, all because the entire system of measuring economic performance is questionable. National accounts have a profit and loss statement, but no balance sheet. The treasury that should be custodian of nation's assets takes no account of what those assets might be and, for practical purposes, largely treats the environment as worthless. If a tract of forest is clear felled, the loss of flora, fauna and all related benefits is not accounted for. What is more, trashing such natural resources will usually show up positively, as it results in "economic activity" with regard to employment and export. Similarly, the accounting for road accidents will not measure the human suffering or the damage to property, but will rather show a boost to GDP with the increase in measurable activity in hospitals, repair workshops, etc. [10].

On the other hand, what monetary value would be reached figuring out the disasters that might occur due to 
failure of the biosphere and calculating the price of insurance against it, or when faced with the looming possibility of ecological meltdown, estimating the cost of replacing the Earth, which may include finding and colonizing another planet [10]. Scientific self-sufficiency Biosphere 2 experiment [17] involved over US $\$ 240$ million spent on developing the infrastructure to support 8 people for two years in an isolated environment. The project failed and fresh air had to be pumped in to save the lives of the participants. Scaling it to 6.5 billion people on Earth, the Earth is worth around 6500 times the world's current GDP [10].

Just like planting trees may have positive financial consequences, cutting trees may result in financial losses. Cutting a tree in one's backyard may reduce the value of one's home and those in the neighbourhood, lower the sales of local businesses and increase air-conditioning and road maintenance costs. It can be said that money does grow on trees and it is our responsibility to make the most out of this fact [18].

In 1979, the Indian scientist, professor T.M. Das calculated the value of a tree to be $\$ 193.250$ and by revaluation it in 2012 it reached $\$ 710.260$ (Australian dollars) during its life span of 50 years [6]. Thus, the conventional value of a tree, which only accounts for total weight and quality of timber or fruit or biomass it produces and that could be sold in the market, makes about $0.3 \%$ of the real value of a tree. All the rest is oxygen production, conversion to animal flesh and bones, controlling of soil erosion and soil fertility, recycling of water and controlling humidity and air temperature, sheltering of birds, squirrels and insects and removal of suspended particulate matter, $\mathrm{CO}_{2}$ and $\mathrm{SO}_{2}$ from the air.

In the field of accountancy, a special branch of social accountancy and corporate social reporting got incentives from above calculation for determining the social value of natural resources [6]. No method is yet capable of encompassing all values of a certain natural resource, so it is necessary to combine various methods as well as involve experts from different fields in producing such estimates [19].

\section{The Value of Vegetation in the Coastal Area of the Republic of Croatia}

Croatian Forest Act was in the second half of the 20th century gradually supplemented with a great many nonmarket forest functions, indicating growing awareness of the ecological significance of forests. Article 3, paragraph 2 of the Forest Act [20] in force until August 2018 listed the following non-market forest functions:

- protection against erosion caused by water and wind,

- balance of the water regime in the landscape and prevention of torrents and high waters,

- purification of water by filtering through forest soil, and supply of underground streams and water sources with drinking water,
- beneficial impact upon climate and agricultural activities,

- purification of polluted air,

- contribution to landscape beauty,

- creation of beneficial conditions for human health,

- providing space for relaxation and recreation,

- creating conditions needed for developing ecological, hunting and rural tourism

- conservation of gene pool of forest trees and other forest biocenose species

- conservation of biological diversity of gene pool, species, ecosystems, and landscape

- supporting general and special nature protection (national parks etc.) of forest landscape

- mitigating the greenhouse effect by binding carbon and enriching the environment with oxygen,

- general protection and improvement of human environment through the existence of forest ecosystems as biological capital of an enormous value and

- significance in national defence and development of local communities.

The new Forest Act [21], in its Article 4, lists 9 nonmarket forest functions, as a result of regrouping the previous list, introducing general function of protection and improvement of the human environment, but omitting the mention of landscape, erosion caused by wind, water and air purification, development of local communities, and biological capital. In the same Article those functions are now combined with market functions.

Jurjević et al. [8] have pointed out that forestry science and practice brought together in the Croatian Forestry Society designed a method to valuate non-market forest functions with a scale of grades for each individual function whereby the scale of grades represent points whose value is determined in financial terms (in HRK). While determining the value of the non-market forest functions, it was believed that this value was enormous and almost immeasurable. Since capital and politics which ensured that capital gets its way have increasingly encroached upon forests so that the ambitions of building golf courses, roads, vineyard and olive plantations, quarries, etc., could be achieved on the most precious of forest stands, the attempt was made to determine a rational price of the general beneficial forest functions, a price that would confront these ambitions. Policies indulgent towards large capital greatly contribute to non-compliance in valuing by this mentioned method that is included in forestry legislation. By adoption of the Roads Act [22] those become exempted from reimbursing the damage caused by forest conversion. Implementing acts of the Forest Act adopted by the Ministry of Forestry, Agriculture and Water Management, allow precious Mediterranean forestland to be converted into vineyards and olive tree plantations, instead of using abandoned agricultural land for those purposes. Forest ecosystems are in fact paying the price for their clear status 
in the cadastre and land register, unlike agricultural land which is burdened by the fact that its ownership stretches over several generations.

The natural environment in tourist destinations along the Adriatic coast mainly consists of the sea, forests and forestland (rockery or vegetation degradation forms) and it is often a public asset accessible to all. And while the providers of tourist services use such public good as one of the main factors of attraction of the tourist destinations and thus through the sale of tourist service also collect certain rent, the value of public good, and thus also of the Mediterranean forests in tourism has not been systematically researched until mid-nineties [23]. The most comprehensive research, with regard to the aesthetic and recreation value of Croatian coastal forests, was implemented in a period from 1995 to 2001 with regard to tourism and the local community [13].

General beneficial forest functions are also more emphasized in the Mediterranean than inland. Jurjević et al. [8] have emphasized in particular the campsites that use parts of forests under special conditions, where the guest gets close to nature, but inflicts potential damage to the forest, so it is essential that campsite users develop awareness of the importance of the conservation of forests and apply the principles of their protection.

Matić et al. [24] have pointed out that in no other land area of Croatia is the issue of antierosion and water protection function of forests so pronounced as in the Mediterranean. Namely, forests have for centuries been exposed to intense anthropogenic impact in the Mediterranean. Most often it is the matter of a poor use of forests, e.g. irrational and uncontrolled felling for wood as raw material for various purposes, browsing and grazing, takeaway of foliage and litter, truncation and trimming, burning and clearing for extending agricultural areas, conversion of forests and forest land for the purpose of developing infrastructure, tourism, viticulture, olive growing etc. Such long-term impacts in combination with fires, specific climate conditions and erodible soils have led gradually to a general degradation of the Mediterranean forest ecosystems.

In the Croatian part of the Mediterranean, even white hornbeam brushwood has significant anti-erosion and hydrological roles, while maquis fully meets all the beneficial functions. For the said area, it can be argued that every single tree growing upon the rocks of karst is most certainly of an exceptional value as an ecological niche for numerous living creatures. Pubescent and holly oak forests, as well as Mediterranean pines, surround the tourist resorts, offering people recreational and social pleasure in terms of landscape, climate, hiking, and other sports activities, besides providing protection against erosion and torrents. Significant is also the role of rivers in karst surrounded by forests in offering diverse opportunities for water sports [8]. Mediterranean national parks and nature parks with forests as one of their fundamental values provide wide opportunities that substantially boost the value of the general benefit functions of the forest.
The cost of raising a new natural forest until its optimal functions had been achieved in terms of raw material and other benefits which takes at least a whole century, probably more, considering also the loss of both functions for this length of time, calculated by using the principles of economic science, would be enormous, most probably much higher than the one assessed by ecologists who take into account general benefit functions [8].

Tikvić et al. [25] have pointed out that benefits provided by ecosystems to humans and the environment can be hardly valued in monetary terms and that for example the Park forest Marjan represents the most valuable part of nature in the City of Split. Its area should not shrink because of the services it offers to all inhabitants of Split and other visitors. In the same manner, converting natural stable forests into the so-called secondary old-growth forest leads to a significant decrease of their stability and reduced provision of ecosystem services, especially at the stage of aging and decay. Thus, all the forests including park forests should be managed properly in order that they provide all services in an optimum manner. The proof thereof is the latest striking dieback of the Aleppo pine trees in the Park Forest Marjan [19].

Jurjević et al. [8] have concluded that, until full awareness is reached of the priceless value of forests, they will constantly be endangered and the only way to protect them is to assess a high (real) price for this priceless natural asset in order to protect its status safeguarded by the Constitution of the Republic of Croatia. One should therefore be very careful in evaluating the economic price of forests because if values calculated based on the principles of economic science are used, then Mediterranean forests could be bought by almost anybody.

\section{Solutions in the Coastal Area}

Several potential instruments for resolving the tree cutting and deforestation issue or better to say preservation and maintenance of vegetation have been elaborated herein below.

\section{The role of local self-government with regard to natural and legal persons}

Some local self-governments incorporated in their acts the provisions under which it is necessary to secure respective approval for any cutting down undertaken. For instance, the City of Opatija in its Decision on Communal Order [26], Article 15, states the following: „, The owner of a land plot is obliged to secure approval issued by relevant body of the Municipal administration for cutting the trees and other greenery having a trunk diameter exceeding 10 $\mathrm{cm}$ as well as for trimming the branches whose diameter exceeds $10 \mathrm{~cm}$ in his/her proper yard or non-developed building plot on the entire community territory area. The City council of Opatija may upon the mayor's proposal appoint a special expert authority in charge of setting out the 
standards for landscaping the yards on the territory of the City as well as for issuing approvals referred to in the preceding paragraph“.

In the period from $1^{\text {st }}$ January 2015 to $2^{\text {nd }}$ November 2017, a total of 85 requests for cutting trees and other greenery within the meaning of the above mentioned provision were received and processed. The requests, for the most part, complied with and to a lesser partly, along with proposing the measures to be taken. For instance, the approval was solicited for the removal of a tree, while the approval was issued for trimming and shaping of the tree crown along with the proposal that, prior to the removal of the tree, its sanitary status must be monitored for some time [27].

Anyhow, the municipalities could provide for the planting of an appropriate replacement tree in the vicinity, or for the payment of an appropriate high amount that obviously takes into account not only the value of timber but also the actual damage incurred by felling, considering the aforementioned valuation method. The amount payable should correspond to the amount of the damages applicable in the case of a notification of a claim for damages incurred by felling, while the funds could be designated for planting urban trees or forestation.

\section{Fee for forest general benefit functions}

Under the Croatian law [20], the fee for using forest general benefit functions is payable by legal and natural persons carrying out an economic activity in favour of the state budget. Funds collected may be used for financing the activities on the biological renewal of forests, activities related to managing forest in the karst, activities on recovery and restoration of stands threatened by drying and other calamities, construction of forest roads, demining of forest areas and other works indispensable for preserving and improving forest general benefit functions, the works concerning seed and nursery activities in forests, preservation of gene pool, setting clone seed plantations as well as for scientific papers in the field of forestry [28]. The said ordinance designates $5 \%$ of funds for scientific and expert activities as well as for publishing activities, $30 \%$ for demining of forests and forestlands as well as $5 \%$ for fire brigades.

The height of the fee is related to total revenues and amounts to $0.0265 \%$, meaning HRK 265 annually for a company with the annual revenue of one million HRK. However, the problem is that neither the public nor the payers have sufficient knowledge of the mentioned fee [29]. Charging such a fee should be in function of the preservation of forests from the part of each payer, depending on the relationship between the payer and the vegetation or forest ecosystem, with the function of penalizing or stimulating. It is of particular relevance to stress the relationship between the tourist sector and the natural capital in the form of vegetation cover of the coastal karst lands which in itself represents one of the top values of the destination, but which asset is unfortunately not always treated as such in an appropriate manner.

\section{Non-financial reporting}

Elkington [30] holds that a growing portion of the sustainability agenda will by default end up with the business and civil society, the institutions and public activities that create the social context within which markets evolve and business is done. Corporations are being held responsible for a range of activities and non-financial impacts. They are being called to account not only by investors and shareholders but also by politicians, whistle blowers, the media, employees, community groups, prosecutors, classaction lawyers, environmentalists, human rights advocates, public health organizations, and customers [31].

There is a quote by Allen L. White, cofounder of the Global Reporting Initiative (GRI), an organization that issues sustainability reporting guidelines, reading as follows: „Why even bother to distinguish between what is financial information and what is non-financial information? It is all information. Ultimately, the important distinction is whether it is something a reasonable investor or other stakeholder would want to know" [31].

The Non-Financial Reporting Directive 2014/95/EU [32] in its preamble states that the Commission identified the need to raise to a similarly high level across all Member States the transparency of the social and environmental information provided by undertakings in all sectors, that the disclosure of non/financial information is vital for managing change towards a sustainable global economy by combining long-term profitability with social justice and environmental protection and that the disclosure of non-financial information helps the measuring, monitoring and managing of undertakings' performance and their impact on society. Thus by its Article 1 it introduces the concept of non-financial statement. Namely, large undertakings, which are public-interest entities exceeding on their balance sheet dates the criterion of the average number of 500 employees during the financial year, shall include in the management report a non-financial statement containing information to the extent necessary for an understanding of the undertaking's development, performance, position and impact of its activity relating to as a minimum, environmental, social and employee matters, respect for human rights, anti-corruption and bribery matters. Member States shall provide that the provisions are to apply to all undertakings for the financial year starting on $1^{\text {st }}$ January 2017 or during the calendar year 2017.

The Guidelines on Non-financial Reporting [33] state that transparency in reporting contributes to the UN Sustainable Development Goals and to the implementing of the Paris Climate Agreement. It is also argued that disclosure requirements for non-financial information apply to certain large companies with more than 500 employees, as the cost of obliging small and medium-size enterprises to apply them could outweigh the benefits, so the administrative burden is kept to a minimum.

The Guidelines build on various frameworks, one of them being the aforementioned Global Reporting Initiative - GRI. Sustainability reporting is the practice of measuring, 
disclosing and being accountable to internal and external stakeholders for organizational performance towards the goals of sustainable development. It is a broad term considered synonymous with others used to describe reporting on economic, environmental and social impacts (e.g. triple bottom line, corporate responsibility reporting, etc.) [34].

As Member States should not be prevented from requiring disclosure of non-financial information from undertakings and groups other than undertakings that are subject to the Directive [32], the question arises whether it is possible to simplify reporting in a manner that it does not result in an expense. Rendering possible for companies with workforce under 500 to mitigate reporting may result in a substantial public expense or externalization of costs.

The Directive, through the mentioned Guidelines, introduces the concept of materiality in sustainability reporting. Materiality means that information in the report should cover topics and indicators that reflect the organization's significant economic, environmental, and social impacts or those that would substantially influence the assessments and decisions of stakeholders. It should be kept in mind that organizations are faced with a wide range of topics on which they could report. Materiality is the threshold at which topics or indicators become sufficiently important that they should be reported, see fig. 1. The stakeholders can include those who are invested in the organization (e.g. employees, shareholders, suppliers) as well as those who have other relationships to the organization (e.g. vulnerable groups within local communities, civil society, etc.) [34].

The non-financial reporting thus definitely ceases to be mere listing of environmental and social aspects of making business and ever more becomes the quantification, analysis and reporting of material aspects for the company and its stakeholders [35].

When people know that their behaviour is being observed, measured, recorded, and published, they change that behaviour to meet the expectations. When they know

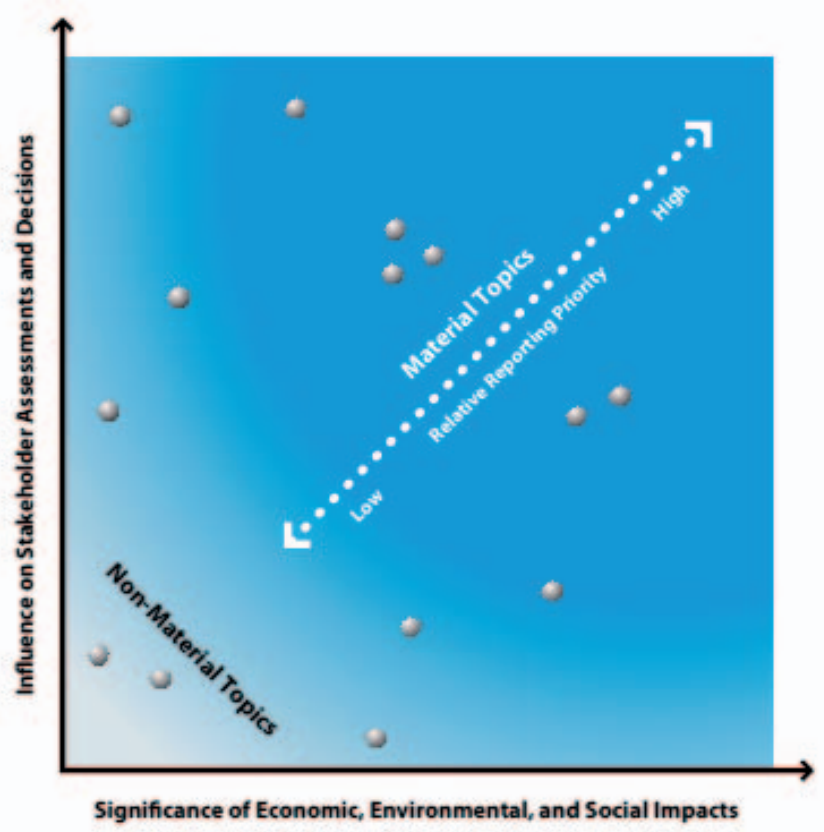

Figure 1 Defining Materiality [34].

(or believe) that their behaviour is not to be measured they tend to slack off. Hence, the well known rule of organizational behaviour is: what gets measured gets done. The very establishment of a reporting mechanism creates pressure on companies to improve their behaviour [31].

The environmental GRI Performance indicators [34] assumed to be material for most organizations are listed in Table 1.

When defining sustainability metrics for reporting purposes, it is necessary to establish goals that further the primary objectives of the business. For a commercial bank, for example, conducting robust due diligence on the community or environmental impacts of its loans would be a far more significant sustainability goal than reducing water and waste or recycling paper [31]. Furthermore, a company may consider that impacts through its upstream

Table 1 Selected Environmental GRI Performance Indicators Material for Organizations and Relevant to Natural Capital

\begin{tabular}{|l|l|}
\hline Environmental aspect & \multicolumn{1}{c|}{ Indicator } \\
\hline Biodiversity & $\begin{array}{l}\text { EN11 Location and size of land owned, leased, managed in, or adjacent to, protected areas and areas of high } \\
\text { biodiversity value outside protected areas }\end{array}$ \\
\cline { 2 - 2 } & $\begin{array}{l}\text { EN12 Description of significant impacts of activities, products, and services on biodiversity in protected } \\
\text { areas and areas of high biodiversity value outside protected areas }\end{array}$ \\
\cline { 2 - 2 } & EN13 Habitats protected or restored \\
\cline { 2 - 2 } & EN14 Strategies, current actions, and future plans for managing impacts on biodiversity \\
\hline \multirow{2}{*}{$\begin{array}{l}\text { Emissions, effluents, } \\
\text { and waste }\end{array}$} & $\begin{array}{l}\text { EN15 Number of IUCN Red List species and national conservation list species with habitats in areas } \\
\text { affected by operations, by level of extinction risk }\end{array}$ \\
\hline Products and services & EN26 Initiatives to mitigate environmental impacts of products and services, and extent of impact mitigation \\
\hline Compliance & $\begin{array}{l}\text { EN28 Monetary value of significant fines and total number of non-monetary sanctions for non-compliance } \\
\text { with environmental laws and regulations }\end{array}$ \\
\cline { 2 - 2 } & EN30 Total environmental protection expenditures and investments by type \\
\hline
\end{tabular}


supply chain are relevant and material issues and report on them accordingly. For example, a company producing mineral water may consider specific measures taken to protect the hydric resources it relies upon. A company having impacts on land use and ecosystem change (for example deforestation), directly or through its supply chain, may consider appropriate disclosures on the due diligence applied. In addition, a company disclosing certain key performance indicators may increase transparency by providing information on purpose and link to the company strategy. Moreover, a company may disclose how it approaches a sustainable business strategy and how environmental, social and governance performance can help achieve its business goals. Furthermore, a company may disclose relevant information on how it identifies, assesses, and manages climate-related risks and/or natural capital [33].

A particular focus should be on the practice of companies operating in tourist sector and the entities financing them in reporting their relationship towards natural capital (see also [36]). Systems thinking should also be kept in mind which tells that sustainability cannot be defined for a single corporation, but for a complete economic-socialecological system [30].

\section{Obligations under the Accounting Law}

Intention of the latest Accounting Law [37] is to enhance transparency of large and competitiveness of small and medium-size enterprises by introducing the obligation of reporting on company social responsibility or sustainability. As from $1^{\text {st }}$ January 2017, the reporting of non-financial information became much more detailed and, pursuant to Directive, it should also include the description of material or significant risks that have an impact on operations of an entrepreneur as well as of the products or services that may bring about negative impacts, specifying how the entrepreneur manages such risks. The environmental aspect of reporting on social responsibility consists of relevant indicators by means of which an entrepreneur evaluates the impact of its operations as well as the impact of its products and services on the environment, such as production technology and efficiency of exploiting natural resources. The social aspect, among others, consists of the indicators of inclusiveness of an enterprise in the development of a local community and the issues of human and labour rights [35].

Furthermore, by virtue of Article 27 of the Accounting Law, large entrepreneurs of public interest operating in mining and exploitation or felling of primary forests have an obligation of drafting a report on payments to the public sector. The amount of individual payments made in favour of the public sector exceeding HRK 750,000 must be incorporated in such report.

Pursuant to the principle "think small first", the intention is to diminish for small and medium enterprises the overall regulatory burden at European and national level. For that reason, the requirements under Labour Act and the mentioned Directive on Disclosure of Non-financial
Information concern only certain large entrepreneurs and groups of public interest. Pursuant to Articles 5 and 6 of the Accounting Law, large entrepreneurs and groups of public interest involve those entities of public interest who fulfil two out of three criteria with regard to total assets (HRK 150,000), total revenue (HRK 300,000) and average number of employees (500).

\section{Entities that are not companies}

The provisions of the Accounting Law do not apply to state budget, local and regional self-government units and budget beneficiaries that have entered in the Register of Budget and Extra Budgetary Beneficiaries that administer their financial operations and accounting pursuant to the Budget Law [39]. The provisions of this legislative act concern neither national nor foreign associations and their alliances, trusts, foundations, institutions, art organizations, chambers, trade unions, employers' associations nor other legal persons who administer their operations and accounting pursuant to the Act on Financial Operations and Accounting of Non-profit Organizations [39].

In the Budget Law, there is no reporting obligation as required by the Accounting Act and budget beneficiaries are not bound to deliver such reports.

Niemann [40] states that, in international context, a growing number of local governments are engaged in sustainability reporting, voluntary and responding to legal pressures. Diverse practices emerged based on unique choices concerning formats, periodicity, authorship, and dissemination efforts. Such design questions and associated outcomes are relevant for practitioners yet unaddressed in standard guidelines and most prior research that primary concern content and conjured reporting benefits. The United Nations Sustainable Development Goals (SDG), specifically SDG target 12.6, calls for increased reporting by all types of institutions. The aforementioned EU Directive 2014/95/EU requires all large „public-interest entities“ start disclosing nonfinancial and diversity information. France mandated all municipalities with more than 50,000 inhabitants to periodically produce sustainability reports and similar legislation is mooted elsewhere.

It has to be pointed out that, in the private and public sector, some critics fear accountization where sustainability reports are merely „an outlet for greenwashing or a source of managerialist information that may reinforce business-as-usual and greater levels of un-sustainability". In a less extreme scenario, reporting may lack or lose its benefits. Unfortunately, academic literature shows little consideration for these real-world phenomena. In 2005, GRI launched sustainability reporting guidelines for the public sector that suggested addressing these information types, namely organizational performance, public policies and contextual issues (see figure 2). The focus is to provide reporting guidance on the first and second type of information. Reporting obligation on wider, city-level indicators should apply to many public-sector organizations, 
such as utilities and universities. Disregarding 'state of the environment' monitoring is particularly unsatisfactory for governments as they are organized along jurisdictional lines and enjoy certain control [40].

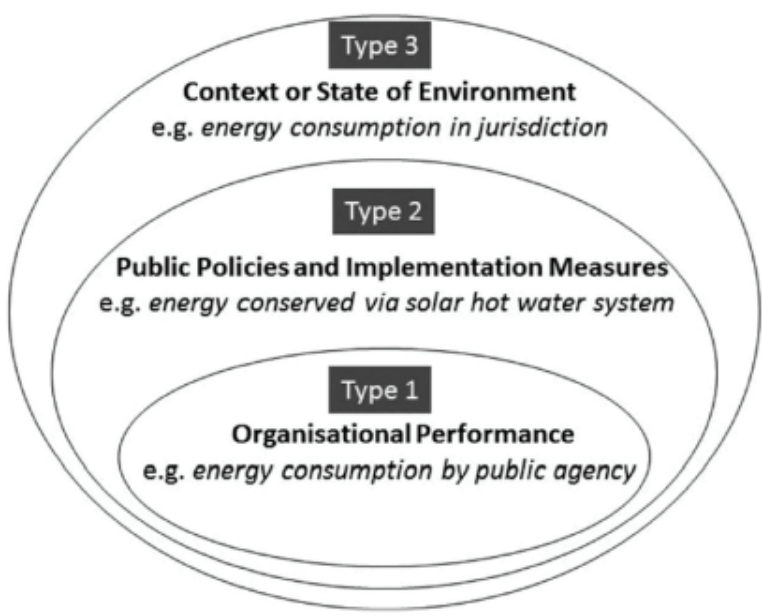

Figure 2 Information Types in Public-sector Reports According to GRI [40].

In some cities sustainability reporting started with enthusiasm, but later stopped, following what practitioners describe as a „reporting fatigue“. Positive effects associated with initial reports were perceived to wear out in the face of decreasing internal „learning curves" or reduced public interest. High frequency ends up being a lot of work and many things are repeating. A repeating system should be designed with a continued use and usefulness [40].

\section{Conclusion}

Conservation of natural capital in the coastal area may be achieved in various ways. The paper has discussed, in particular, the role of local self-governments with regard to individuals and companies, the charges for consuming forest public benefit functions, and non-financial reporting.

Besides the obligation to secure the approval of municipalities for cutting down the trees, local self-government units could prescribe planting of an appropriate replacement tree in the vicinity, or payment of appropriate high amount that obviously takes into account not only the value of timber but also the actual damage incurred by felling.

Charging the fee for forest general benefit functions should depend on a specific relationship between the payer and the vegetation or forest ecosystem. A particular emphasis should be placed on non-financial reporting material for organizations operating in the tourist sector, relevant to natural capital.

National legislation should precisely, for the sake of the specific character of the natural capital in the Republic of Croatia, meet more than a minimum compliance with the EU directives and international efforts in standardizing non-financial reporting.
In the same manner, the coverage of liable entities should be also broadened to the companies exceeding defined revenue limits, assets and number of employees referred to in the Directive when those by virtue of undertaking their activity may and do exert pressure on the vegetation cover or natural capital.

Furthermore, the entities of public interest are also local and regional self-government units and the companies established by them as well as other public entities that in the field of their jurisdiction or activity highly affect natural capital. Those should become liable to non-financial reporting.

\section{References}

[1] CODER KD 2017 Identified benefits of Community Trees and Forests, Warnell School of Forestry and Natural Resources - University of Georgia, WSFNR-17-02, 6 p. URL: http://www.warnell.uga.edu/sites/default/files/publications/WSFNR-17-02\%20Coder_0.pdf (10 June 2018)

[2] WEBER JP 1999 Determining the Value of Trees, IRWA, $6 \mathrm{p}$. URL:http://www.irwaonline.org/members/publications/ archives-1990-1999/ (12 February 2018)

[3] WORLD FORESTRY CENTER 1993 A Technical Guide to Urban and Community Forestry, Publications, etc. -- Nebraska Forest Service. 70., 51 p. URL: http://digitalcommons.unl. edu/cgi/viewcontent.cgi?article=1069\&context=nebforest pubs (1 July 2018)

[4] BECKHAM N. 1991 Trees: finding their true value, Australian Horticulture URL: http://www.uow.edu.au/ sharonb/ STS300/valuing/price/pricingarticles.html

[5] THE TELEGRAPH 2014 How much is a tree worth, 15 September 2014 URL: http://www.telegraph.co.uk/gardening/ plants/trees/11092440/How-much-is-a-tree-worth.html (22 December 2017)

[6] DAS TM 2012 Revaluation of services of a tree in 2012, Indian Biologist, Vol. 44(1), pp 13-17 URL: http://www.tmdasfoundation.org/Indain $\% 20$ Biologist $\% 20 \mathrm{PDF} /$ Indian $\% 20$ Biologist\%2044(1)\%202012.pdf (28 December 2017)

[7] FRANKS EC, REEVES, JW 1988 A formula for assessing the ecological value of trees, Journal of Arboriculture 14(10): 255-259.

[8] JURJEVIĆ P, PRPIĆ B, VULETIĆ D, JAKOVAC H, POSAVEC S 2011 Evaluation of the non-market functions of Mediterranean forests by using the principles of forestry, ecology and classical economics, Forests of the Croatian Mediterranean, Academy of Forestry Science Zagreb: 516-523.

[9] POSAVEC S BELJAN K, CVJETKOVIĆ N 2016 Valuation of nonwood forest products and services in NP "Krka". BUKGlasnik Javne ustanove "Nacionalni park Krka " (18476511) 7, 14: 14-20.

[10] FITZGERALD K 2006 How do you value a tree? URL: http:// www.earthsharing.org.au/2006/09/how-do-you-value-atree/ (28 November 2017)

[11] CULLINAN C 2008 If nature had rights, Orion Magazine URL: http://orionmagazine.org/article/if-nature-had-rights/ (15 December 2017)

[12] RUNKO LUTTENBERGER L, LUTTENBERGER A 2012 Earthcentric approach in environmental protection. Pomorstvo: Journal of maritime studies, 26(2012), 1: 27-44. 
[13] BELJAN K, POSAVEC S, JERČIĆ K 2015 Economic valuation of urban trees: Ribnjak park case study, Zagreb. South-East European Forestry 6(1)2015: 119-127.

[14] FRANKS EC, REEVES JW 1988 A formula for assessing the ecological value of trees, Journal of Arboriculture, 14(10): 255-259.

[15] KRAVČÍK M, POKORNÝ J, KOHUTIAR J, KOVÁČ M, TÓTH E 2007 Water for the Recovery of the Climate - A New Water Paradigm URL: http://www.waterparadigm.org/ (15 November 2017)

[16] AGROWIKI 2017 Online Agriculture Library: Economic Value of a Tree URL: agrowikipedia.blogspot.hr/2017/01/ economic-value-of-tree.html viewed (8 November 2017)

[17] ODUM EP, BARRETT, GW 2005 Fundamentals of Ecology, Thomson

[18] BIOCARBONENGINEERING 2015 What is the social value of a tree URL:https://www.biocarbonengineering.com/blog/ what-is-the-social-value-of-a-tree

[19] TIKVIĆ I 2017 Procjene usluga ekosustava Park šume Marjan u Splitu, Šumarski fakultet Sveučilišta u Zagrebu

[20] GOVERNMENT OF THE REPUBLIC OF CROATIA 2005 Forest Act (in Croatian), Official Gazette 140/05, 82/06, 129/08, 80/10, 124/10, 25/12, 68/12, 148/13, 94/14, Zagreb, Croatia. URL: https://narodne-novine.nn.hr/clanci/sluzbeni/2005_11_140_2642.html (15 June 2018)

[21] GOVERNMENT OF THE REPUBLIC OF CROATIA 2005 Forest Act (in Croatian), Official Gazette 68/18, Zagreb, Croatia. URL: https://narodne-novine.nn.hr/clanci/sluzbeni/2018_07_68_1392.html (27 July 2018)

[22] GOVERNMENT OF THE REPUBLIC OF CROATIA 2011 Roads Act (in Croatian), Official Gazette 84/11, Zagreb, Croatia. URL: https://narodne-novine.nn.hr/clanci/sluzbeni/2011_07_84_1790.html (1 July 2018)

[23] KRPINA V, ŠPANJOL Ž, JAZBEC A 2014 The role of forests and forestsry in tourism and nature protection in the Zadar County area (in Croatian with English summary). Šumarski list 5-6, 2014: 271-281.

[24] MATIĆ S, ANIĆ I, ORŠANIĆ M 2005 Silvicultural treatments aimed at imrpving the anti-erosion and water-protective role of forests. Šumarski list, 13:17-30.

[25] TIKVIĆ I, UGARKOVIĆ D, PELES I, KNEŽIĆ I, MEDUNIĆORLIĆ G, MARINIĆ S, LUKRECIJA B, ČMRLEC A et al. Assessment of forest ecosystem services and non-market forest functions in Park forest Marjan Split. Šumarski list, 5-6: 277-285.

[26] CITY OF OPATIJA 2009 Decision on communal order (in Croatian) URL: http://www.opatija.hr/files/file/sluzbeniakti/komunalna-djelatnost/odluka\%20o\%20komunalnom\%20redu.pdf

[27] CITY OF OPATIJA 2017 Personal correspondence with the Communal system and environmental protection department 3 November 2017
[28] THE MINISTRY OF AGRICULTURE 2015 Ordinance on the procedure for exercising the right to funds recovered from the fees for forest general benefit functions, Official Gazzette 22/2015, Zagreb, Croatia. URL: https://narodne-novine.nn.hr/clanci/sluzbeni/2015_02_22_455.html (10 June 2018)

[29] GALLO C, VINCENC G 2017 Što je to OKFŠ i koja je njegova važnost za Hrvatsku, Hrvatske šume br. 252

[30] ELKINGTON J 1999 Cannibals with Forks - The Triple Bottom Line of 21st Century Business, Capstone Publishing Limited, Oxford Centre for Innovation, Oxford

[31] SAVITZ AW 2014 The Triple Bottom Line, John Wiley \& Sons, Inc., San Francisco

[32] EUROPEAN UNION 2014 Directive 2014/95/EU of the European Parliament and of the Council of 22 October 2014 amending Directive 2013/34/EU as regards disclosure of non-financial and diversity information by certain large undertakings and groups, OJ L 330, 15.11.2014 p. 1-9.

[33] EUROPEAN COMMISSION Communication from the Commission - Guidelines on non-financial reporting (methodology for reporting non-financial information) C/2017/4234, OJ C 215, 5.7.2017, p. 1-20.

[34] GLOBAL REPORTING INITIATIVE GRI 2000-2011 Sustainability Reporting Guidelines, version 3.1

[35] VUKIĆ N 2015 Izvještavanje o nefinancijskim informacijama prema novom Zakonu o računovodstvu i Direktivi 2014/95/EU. RRIF 12: 46-50.

[36] RUNKO LUTTENBERGER L, LUTTENBERGER A 2018 The role of insurance and tourism industries in achieving climate resilience In: Milohnić I, Smolčić Jurdana D (eds), Tourism and Hospitality Industry 2018 - Trends and Challenges, Opatija, Croatia 26-27 April 2018. University of Rijeka, Faculty of Tourism and Hospitality Management, Opatija, Croatia, pp. 383-393.

[37] GOVERNMENT OF THE REPUBLIC OF CROATIA 2015 Accounting Law (in Croatian), Official Gazette 78/15, Zagreb, Croatia. URL: https://narodne-novine.nn.hr/clanci/sluzbeni/2015_07_78_1493.html (15 March 2018)

[38] GOVERNMENT OF THE REPUBLIC OF CROATIA 2008 Budget Law (in Croatian), Official Gazette 87/08, 136/12, 15/15, Zagreb, Croatia. URL: https://narodne-novine.nn.hr/clanci/ sluzbeni/2008_07_87_2791.html (15 March 2018)

[39] GOVERNMENT OF THE REPUBLIC OF CROATIA 2014 Act on financial operations and accounting of non-profit organizations (in Croatian), Official Gazette 121/14. URL: https:// narodne-novine.nn.hr/clanci/sluzbeni/2014_10_121_2300. html (16 March 2018)

[40] NIEMANN L 2018 Sustainability reporting by local governments: a magic tool? Lessons on use and usefulness from European pioneers. Public management Review, Vol. 20, Issue 1 